\author{
Martyna Cader \\ Uniwersytet Rolniczy w Krakowie, Polska - University of Agriculture in Krakow, Poland \\ JULIA GORZELANY \\ Uniwersytet Rolniczy w Krakowie, Polska - University of Agriculture in Krakow, Poland
}

\title{
Funkcja turystyczna jako element konkurencyjności miasta Szczyrk w czasie pandemii COVID-19
}

\section{Tourist function as an element of the competitiveness of Szczyrk (Poland) during the COVID-19 pandemic}

\begin{abstract}
Streszczenie: Celem artykułu jest ocena funkcji turystycznej jako czynnika konkurencyjności na przykładzie miasta Szczyrk. Wnioski płynące z tej analizy mogą dotyczyć także innych miejscowości o charakterze turystyczno-górskim. Ponadto w tekście zbadano wpływ pandemii COVID-19 na sektor turystyki - w tym celu prześledzono literaturę, zarówno polską, jak i zagraniczną, a także przeanalizowano dane statystyczne. Rozważania te uzupełniono o pilotażowe badania własne, w których wykorzystano autorski kwestionariusz ankiety oraz wywiady eksperckie. Główny wniosek, jaki postawiono w artykule, brzmi: funkcja turystyczna ma zasadniczy wpływ na konkurencyjność miasta Szczyrk, a obecna sytuacja epidemiologiczna na świecie pokazuje, że w obliczu nieprzewidywalnych zdarzeń branża turystyczna może być zagrożona. Dlatego też zebrane w artykule doświadczenia przedsiębiorców mogą być pomocne w przygotowaniu sektora turystycznego na ponowny kryzys.
\end{abstract}

Summary: The aim of the article was to evaluate the tourist function as a competitive factor of Szczyrk (Poland). The impact of the COVID-19 pandemic on the tourism sector was also investigated. In order to achieve the goal, an analysis of Polish and foreign literature was carried out, including statistical data. The considerations were supplemented with own research, in which the author's questionnaire and expert interviews were used. The research was of a pilot nature and was carried out in Szczyrk and its vicinity. The main conclusion of the article is: the tourist function has a significant impact on the competitiveness of Szczyrk, at the same time the current epidemiological situation in the world shows that due to unforeseen events, the tourism industry may be endangered. Thus, it poses a real threat to Szczyrk, which may turn from a competitive town into an unattractive tourist destination in one day.

Słowa kluczowe: konkurencyjność; kryzys; pandemia COVID-19; rozwój Szczyrku; sytuacja turystyczna

Key words: competitiveness; COVID-19 pandemic crisis; development of Szczyrk; tourism

Otrzymano: 2 kwietnia 2021

Received: 2 April 2021 
Zaakceptowano: 20 czerwca 2021

Accepted: 20 June 2021

\section{Sugerowana cytacja/Suggested citation:}

Cader, M., Gorzelany, J. (2021). Funkcja turystyczna jako element konkurencyjności miasta Szczyrk w czasie pandemii COVID-19. Przedsiębiorczość - Edukacja [Entrepreneurship - Education], 17(2), 105-120. https://doi.org/10.24917/20833296.171.8

\section{Wstęp}

Nie ulega wątpliwości, że poszczególne miasta, aby się rozwijać, muszą zabiegać o zainteresowanie klientów i inwestorów. Z kolei miejscowości charakteryzujące się atrakacyjnością turystyczną rywalizują ze sobą o przyciągnięcie jak największej liczby podróżujących. Z tych względów zjawisko konkurencyjności jest niezwykle ważnym obszarem, wokół którego skupia się uwaga naukowców oraz praktyków gospodarczych. Celem niniejszego opracowania jest analiza funkcji turystycznej jako elementu kształtującego konkurencyjność Szczyrku. Ponadto w tekście zbadano opinie na temat wpływu pandemii COVID-19 na turystykę w tym mieście, gdyż, jak stwierdzono, miała ona negatywny wpływ na gospodarkę światową, w tym na przemysł turystyczny (Hall et. al, 2020; Yu et al., 2020). W artykule postawiono następujące pytania badawcze:

- Czy funkcja turystyczna wpływa na konkurencyjność Szczyrku?

- Jak sytuacja związana z pandemią COVID-19 wpłynęła na branżę turystyczną?

- Czy w przyszłości sektor turystyczny może ponownie mierzyć się z podobnym wyzwaniem?

W celu odpowiedzi na powyższe pytania przeprowadzono analizę literatury - zarówno polskiej, jak i zagranicznej. Dane statystyczne pozyskano z Banku Danych Lokalnych (BDL). Wybrane wskaźniki opisujące sytuację turystyczną miasta i wyniki badań ankietowych przedstawiono na wykresach. Część graficzna została opracowana na podstawie metadanych pobranych ze strony Głównego Urzędu Geodezji i Kartografii (GUGiK) i BDL-u. Załączone mapy wykonano z wykorzystaniem programu QGIS, a mapy myśli z wykorzystaniem strony MindMeister. Ponadto w maju 2020 r. zostało przeprowadzone badanie pilotażowe na podstawie autorskiego kwestionariusza i wywiadów eksperckich. Wpływ funkcji turystycznej na konkurencyjność Szczyrku został wówczas poddany ocenie turystów, mieszkańców miasta i okolic, a także inwestorów oraz osób pracujących na terenie miasta.

\section{Konkurencyjność i funkcja turystyczna w ujęciu teoretycznym}

W latach siedemdziesiątych XX w. nastąpił wzrost zainteresowania tematem konkurencyjności. Od tamtego czasu powstało wiele definicji konkurencyjności, choć żadna z nich nie zyskała akceptacji wszystkich ekonomistów (Daszkiewicz, 2008; Godlewska-Majkowska, Skrzypek i Płonka, 2016; Ratajczak-Mrozek, 2010). Żeby dobrze zrozumieć istotę tego zjawiska, należy najpierw zapoznać się z terminami, które są z nim związane. Punkt wyjścia stanowi tu definicja konkurencji, z którą konkurencyjność jest bardzo często mylona. Podstawowa różnica między tymi pojęciami polega na tym, że konkurencja jest czynnością wykonywaną przez rywalizujące obiekty. Natomiast konkurencyjność 
to właściwość obiektu konkurencyjnego (Michalak, 2014). W regionach turystycznych zachodzą bardzo złożone procesy rozwojowe, przez co wyodrębnienie czynników kształtujących i mających wpływ na konkurencyjność jest bardzo skomplikowane (Góralski, Lazarek, 2009). Uważa się jednak, że konkurencyjność regionalna jest głównym motorem wzrostu dochodów w poszczególnych miastach (Mas-Verdu et al., 2020).

Elementami, które składają się na konkurencyjność, są m.in.: potencjał konkurencyjności, przewaga konkurencyjna, instrumenty konkurowania i pozycja konkurencyjna. Źródłem przewagi konkurencyjnej są składniki potencjału konkurencyjności (Lubomska-Kalisz, 2013).

Konkurencyjność miast i regionów to złożone zagadnienie i zdefiniowanie go wymaga uwzględnienia wielu czynników, np. pojęcie to można rozpatrywać jako dynamikę rozwoju gospodarczego miasta lub regionu (Smętkowski, 2011). O konkurencyjności obszarów turystycznych decydują czynniki egzogeniczne (np. położenie geograficzne, sezonowość, moda) i endogeniczne (m.in. walory turystyczne, dostępność komunikacyjna, promocja; Łaźniewska i Gorynia, 2012). Mimo że turystyka, jako jeden z obecnie wiodących sektorów przemysłu, charakteryzuje się tym, że ciągle ewoluuje, można wskazać dwie podstawy jej rozwoju. Są to środowisko naturalne oraz zasoby społeczno-kulturowe (Marković et al., 2017). Oznacza to, że na atrakcyjność danego regionu istotny wpływ mają walory turystyczne i infrastruktura turystyczna (Bąk, Matlegiewicz, 2010; Dąbrowska, 2010) - bogaty turystycznie region zachęca do inwestowania i zwiększa ruch turystyczny (Nawrot, Zmyślony, 2009).

W przypadku jednostek podziału administracyjnego funkcja turystyczna jest uważana za miernik przestrzeni - przestrzeń jest bowiem jednocześnie wykorzystywana przez turystów i podmioty gospodarcze działające na danym terenie. Uczeni z różnych dziedzin często traktują funkcję turystyczną jako jeden z ważniejszych czynników determinujących zmiany funkcjonalne na obszarach miejskich i wiejskich. Literatura dostarcza wielu definicji funkcji turystycznej. Na przykład niektórzy autorzy wyróżniają w jej obrębie perspektywy geograficzną i ekonomiczną (Krukowska, Świeca, 2011). Poza tym funkcję turystyczną można przedstawić za pomocą różnych miar i cech jakościowych. Rozwój funkcji turystycznej jest zazwyczaj mierzony za pomocą środków opartych na wielkości zakwaterowania, ruchu turystycznego, liczby pracowników w usługach turystycznych lub dochodów z turystyki (Durydiwka, 2013; Szromek, 2013).

Duża odpowiedzialność za zarządzanie turystyką i jej rozwój spoczywa na samorządach lokalnych. Jednostki samorządu terytorialnego są bowiem do tego najlepiej przygotowane ze względu na wiedzę o danym obszarze. Dlatego też trudno osiągnąć zrównoważony rozwój turystyki bez dużego zaangażowania władz lokalnych (Nunkoo, 2015).

\section{Pandemia COVID-19 a turystyka}

Pandemia COVID-19 wywołana wirusem SARS-CoV-2 wpłynęła na gospodarkę na całym świecie. Oddziaływanie pandemii koronawirusa na sytuację ekonomiczną jest niezwykle trudne do oszacowania $\mathrm{z}$ powodu niewystarczających danych statystycznych (Stock, 2020). Brak szczepionek i brak skutecznego leku przeciwko wirusowi sprawiły, że działania pozamedyczne były główną strategią powstrzymywania pandemii. Dlatego też w marcu 2020 r. turystyka w dużej mierze ustała. Wstrzymanie podróży międzynarodowych, ograniczenia dotyczące zgromadzeń publicznych i mobilności dotyczyły ponad 
90\% światowej populacji (Gössling, Scott i Hall, 2020). Spadek popytu na usługi turystyczne i hotelarskie spowodował poważne problemy finansowe. Na światowym rynku hotelarsko-gastronomicznym 30-40\% przedsiębiorstw zostało zmuszonych do zaprzestania działalności. W rezultacie ok. $75 \mathrm{mln}$ osób straciło pracę (Sheresheva et al., 2021). Z tych względów obszary turystyczne powinny podjąć pewne działania zapobiegawcze, które uchronią ten sektor przed ewenualnym ponownym kryzysem (Duro et al., 2021). Z tych właśnie względów czas pandemii COVID-19 jest uznawany za przełomowy dla turystyki (Higgins-Desbiolles, 2020), a wysokie ryzyko przyszłych pandemii postawiło przed nią nowe wyzwania (Streimikiene et al., 2021).

Omawiana sytuacja została przedstawiona na przykładzie Polski w postaci kartodiagramu słupkowego (rycina 1). Można na nim zauważyć gwałtowny spadek liczby osób korzystających z usług turystycznych w czasie wybuchu pandemii COVID-19 w porównaniu z rokiem 2019. Podobnie wyglądało to na całym świecie - anulowane wydarzenia, zamknięcie restauracji, obiektów i atrakcji stało się natychmiast odczuwalne w innych częściach łańcucha dostaw (np. catering i usługi pralnicze). W ciągu kilku miesięcy obszary wysoce turystyczne stały się nieturystyczne (Gössling, Scott i Hall, 2020). Właśnie w tym kontekście szczególnie wartościowy staje się wpływ badaczy na przeprojektowanie programu nauczania - ich działanie miałoby na celu przygotowanie przyszłych liderów branży na prowadzenie bardziej odpowiedzialnych działań w zakresie podróży i turystyki.

Należy jednak wspomnieć o wymiernych korzyściach sytuacji pandemicznej, a mianowicie o wpływie kryzysu na globalne emisje i jakość powietrza (Ioannides, Gyimóthy, 2020).

Rycina 1. Turyści w Polsce w marcu 2019 r. i 2020 r. (z podziałem na województwa)

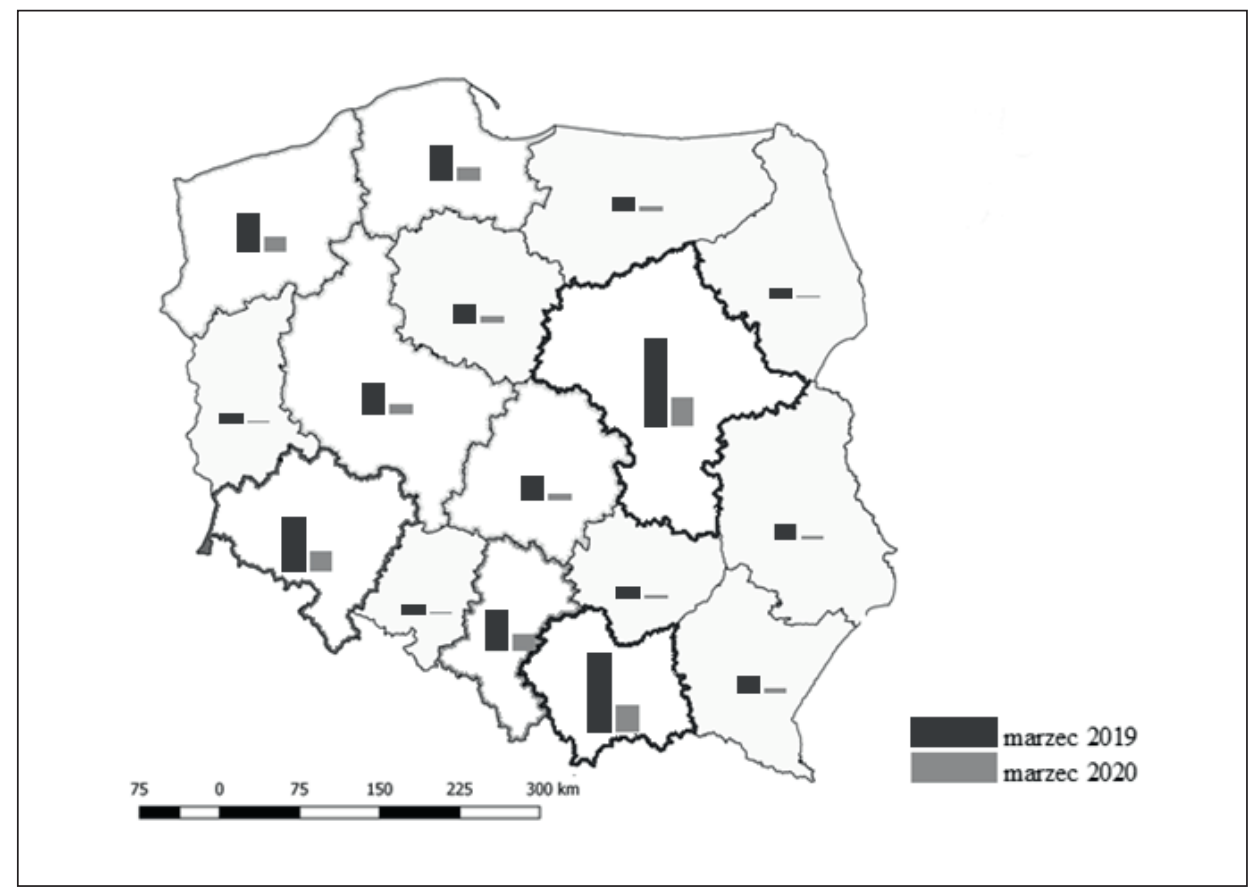

Źródło: Opracowanie własne na podstawie danych pozyskanych z BDL-u (GUS, 2021, 15 listopada) 


\section{Obszar badawczy}

Góry zajmują 24\% powierzchni Ziemi. Obszary górskie są jedną z najpopularniejszych destynacji turystycznych na świecie - stanowią ok. 15\% turystyki na całym świecie i generują przychód między 70 a 90 mld dolarów rocznie. Ma to związek z tym, że turystyka górska spełnia wiele potrzeb odwiedzających (Duglio, Beltramo, 2019). Zapewne z tego względu w ostatnich latach wspinaczki, jazda na nartach i piesze wędrówki zyskują na popularności, co z kolei wpływa na rozwinięcie turystyki górskiej (Musa, Thirumoorthi, 2015).

$\mathrm{Na}$ znaczenie regionów górskich dla turystyki mają wpływ takie czynniki jak położenie geograficzne, opinie turystów górskich i wspinaczy, a także zdjęcia umieszczane w mediach społecznościowych (Ghazali, Thompson-Carr i Higham, 2015). Ponadto turystyka górska jest mniej ograniczona i bardziej zróżnicowana od turystyki przybrzeżnej (Dogan, 2012).

Miasto Szczyrk zostało wybrane jako obszar badawczy ze względu na swoje górskie położenie, które zdecydowanie sprzyja rozwojowi turystyki. Według podziału Kondrackiego Szczyrk znajduje się w podprowincji zewnętrznych Karpat Zachodnich, jego makroregionem są Beskidy Zachodnie, mezoregionem jest zaś Beskid Śląski. To właśnie w Szczyrku znajduje się najwyższy szczyt tego pasma górskiego - Skrzyczne (Knura, Borońska, Włodrczyk, 2016; Foryś, 2000).

$\mathrm{Na}$ terenie miasta funkcjonuje wiele obiektów noclegowych - na dzień 31 lipca $2019 \mathrm{r}$. było ich 35 (2907 miejsc noclegowych). Ośrodki wczasowe mogą przyjąć 696 turystów, a w pokojach gościnnych można przenocować 148 osób. Najwięcej miejsc noclegowych

Rycina 2. Położenie administracyjne Szczyrku

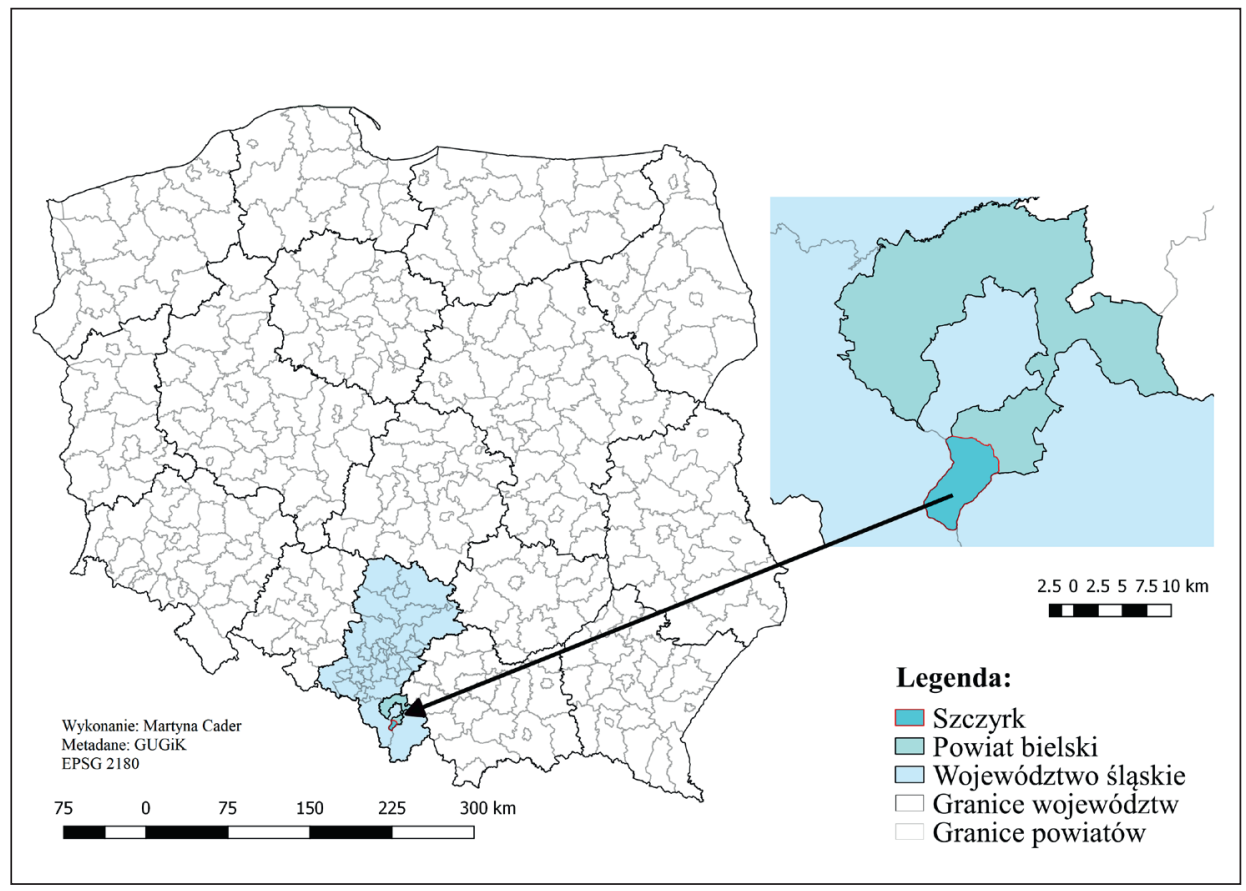

Źródło: Opracowanie własne na podstawie GUGiK (2021, 15 listopada) 
Rycina 3. Liczba noclegów oferowanych w Szczyrku w latach 2014-2018

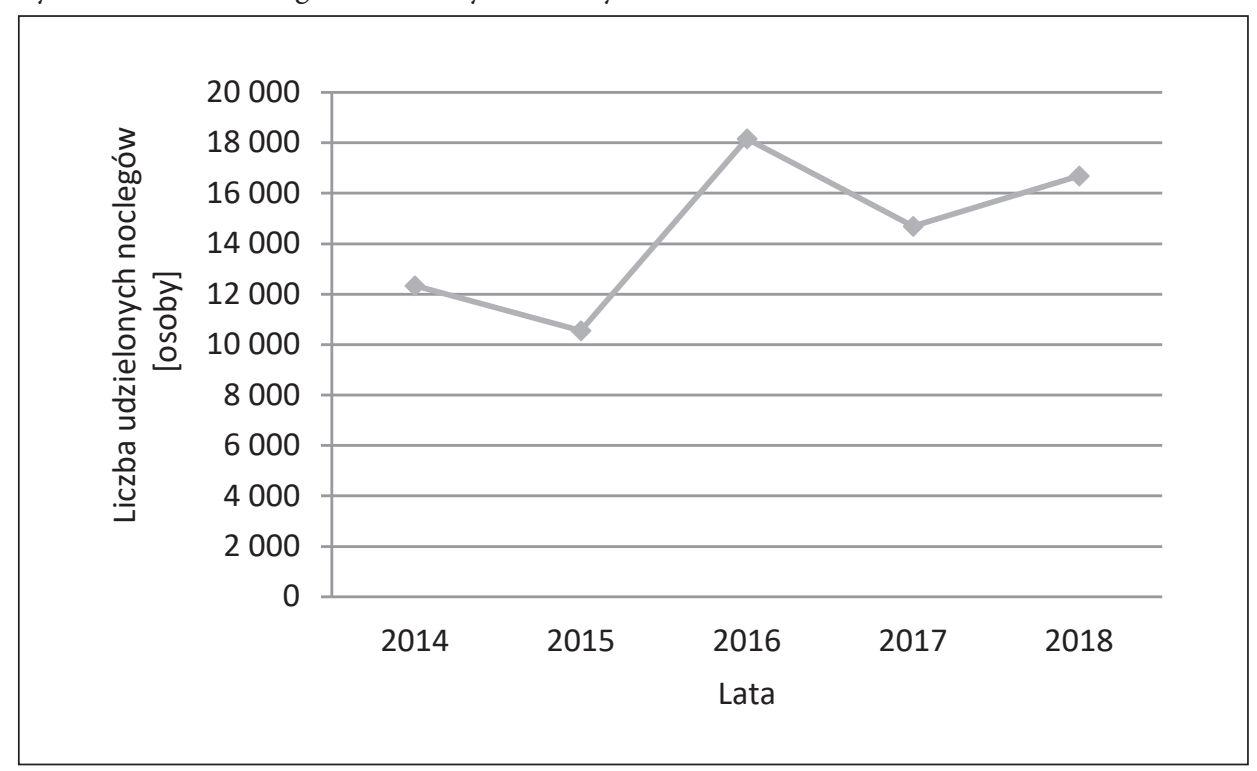

Źródło: Opracowanie własne na podstawie danych pozyskanych z BDL-u (GUS, 2021, 17 listopada)

oferuje pięć hoteli znajdujących się na terenie miasta. Z kolei najmniejszą liczbą miejsc dysponują pensjonaty, szkolne schroniska młodzieżowe, zespoły domków turystycznych i obiekty agroturystyczne (GUS, 2021, 16 listopada).

Na rycinie 3 przedstawiono liczbę oferowanych noclegów w latach 2014-2018. Dynamika zmian wykazuje największy wzrost (o 72,12 punktów procentowych) między rokiem 2015 a 2016, największy spadek (o 19,06 punktów procentowych) odnotowano zaś w roku 2017. Na ogólny wzrost liczby dostępnych noclegów mogła mieć wpływ modernizacja Szczyrkowskiego Ośrodka Narciarskiego (SON). Spółka Taty Mountain Resorts (TMR) w 2014 r. nabyła aż 97\% udziałów na terenie ośrodka, co przełożyło się na funkcjonowanie tej inwestycji (TMR, 2021, 15 listopada).

Funkcja turystyczna a konkurencyjność Szczyrku

(z uwzględnieniem wpływu pandemii COVID-19) - metody badawcze

Proces badawczy został podzielony na cztery etapy. W pierwszym przeanalizowano literaturę polską i zagraniczną oraz dane statystyczne, ponadto przeprowadzono obserwacje. Drugim etapem było zidentyfikowanie obszaru badań. Trzeci etap to badania własne, które oparto na badaniach ankietowych oraz pogłębionych wywiadach eksperckich - pozwoliły one na wskazanie pewnych rekomendacji i kierunków zmian dla Szczyrku. Badania własne (ankietowe), w których wykorzystano autorski kwestionariusz, miały charakter pilotażowy. W maju 2019 r. w związku z pandemią COVID-19 sytuacja, w której znalazły się Szczyrk oraz inne miasta spełniające podobne funkcje turystyczne, była wciąż nieznana. Ponieważ przeprowadzenie ankiety było bardzo utrudnione, wykorzystano w tym celu technikę CAWI (Computer Assisted Web Interview), a kwestionariusze udostępniono za pośrednictwem mediów społecznościowych (Facebook, Instagram). 
Ankietę przeprowadzono wśród mieszkańców Szczyrku i okolic (do $15 \mathrm{~km}$ ), a badania trwały miesiąc. Otrzymano 87 poprawnie wypełnionych ankiet. Wywiady pogłębione przeprowadzono telefonicznie. Zaproszeni do badania anonimowi eksperci pochodzili ze Szczyrku, np. jeden z wywiadów został przeprowadzony z przedstawicielem przedsiębiorstwa turystycznego.

Kwestionariusz składał się z metryczki, która pozwoliła na opisanie próby badawczej, oraz z części zasadniczej, w której zawarto pytania dotyczące wpływu funkcji turystycznej na konkurencyjność Szczyrku. Wśród respondentów największy udział miały kobiety (71,3\%). Zdecydowana większość ankietowanych miała wykształcenie wyższe (60,9\%). Dużą grupę stanowiły osoby z wykształceniem średnim (28,7\%), a najmniej liczną grupę - osoby z wykształceniem podstawowym, gimnazjalnym lub bez wykształcenia (2,3\%). Przeważającą grupę wiekową respondentów stanowiły osoby w wieku 19-25 lat (57,5\%). Udział grupy wiekowej 26-35 lat wynosił 24,1\%, a osób powyżej 35 roku życia - 18,4\%. Wśród ankietowanych nie było osób z grupy wiekowej 0-18 lat. Prawie 70\% respondentów to osoby zamieszkujące Szczyrk lub jego okolice, 30\% stanowili turyści.

\section{Wyniki badań}

Z badań przedstawionych na rycinie 4 wynika, iż zaledwie $2 \%$ respondentów uważa, że Szczyrk nie jest atrakcyjnym turystycznie celem podróży. Według nich miasto dysponuje niewielką ofertą gastronomiczną, a inwestycje prowadzone przez słowacką spółkę Tatry Mountain Resorts doprowadziły do zniszczenia lasu i przeludnienia. Według $80 \%$ respondentów - mimo pandemii COVID-19 - Szczyrk jest atrakcyjnym miejscem wypoczynku (zwłaszcza że w maju 2020 r. uruchomiono proces odmrażania gospodarki).

Ciekawym aspektem jest stosunek respondentów do podróży w czasie pandemii, należy przy tym zaznaczyć, że głosy ankietowanych były podzielone. Największy udział (27\%) stanowiły osoby, które nie boją się podróżowania. Część respondentów (25\%) odwołała swoje plany wakacyjne ze strachu przed wirusem. Pozostali ankietowani (prawie 50\%) nie zrezygnowali z podróży, mimo że $25 \%$ z nich miało pewne obawy. Według $60 \%$ badanych turystyka może sprawnie prosperować mimo wprowadzonych ograniczeń.

Z usług świadczonych przez ośrodki narciarskie nie korzysta ponad 57\% respondentów. Dzieje się tak dlatego, że zdecydowana większość z nich (70\%) nie uprawia sportów zimowych. Powodem są także brak czasu, nieatrakcyjna oferta i inne preferencje. W mieście znajduje się wiele atrakcji, które są dostępne również latem (m.in. enduro czy turystyka piesza). Aż 71,3\% badanych korzysta $\mathrm{z}$ dostępnych tras spacerowych i rowerowych. Jeszcze więcej respondentów (77\%) odwiedza malownicze szlaki turystyczne. Warto przy tym zaznaczyć, że zaledwie 5\% ankietowanych uważa, że walory turystyczne nie mają wpływu na konkurencyjność Szczyrku. Z kolei 95\% badanych sądzi, że uwarunkowania przyrodnicze są elementem decydującym o atrakcyjności regionu.

Za sprawą przeprowadzonej ankiety zbadano także poziom zadowolenia z podstawowych elementów turystyki w mieście, takich jak ośrodki narciarskie, trasy spacerowe, trasy rowerowe i szlaki turystyki pieszej oraz górskiej. Wyniki przedstawiono na rycinie 5. Wśród osób znających zaplecze narciarskie zbadano zadowolenie z usług świadczonych przez poszczególne ośrodki. Najlepiej ocenionym ośrodkiem narciarskim był SON - to na jego terenie w 2014 r. słowacka spółka TMR przeprowadziła wielomilionowe inwestycje. Respondenci byli również zadowoleni z usług COS-u. Nieco gorzej wypadł ośrodek 
Rycina 4. Konkurencyjność Szczyrku a turystyka czasie pandemii COVID-19 - wyniki badań ankietowych

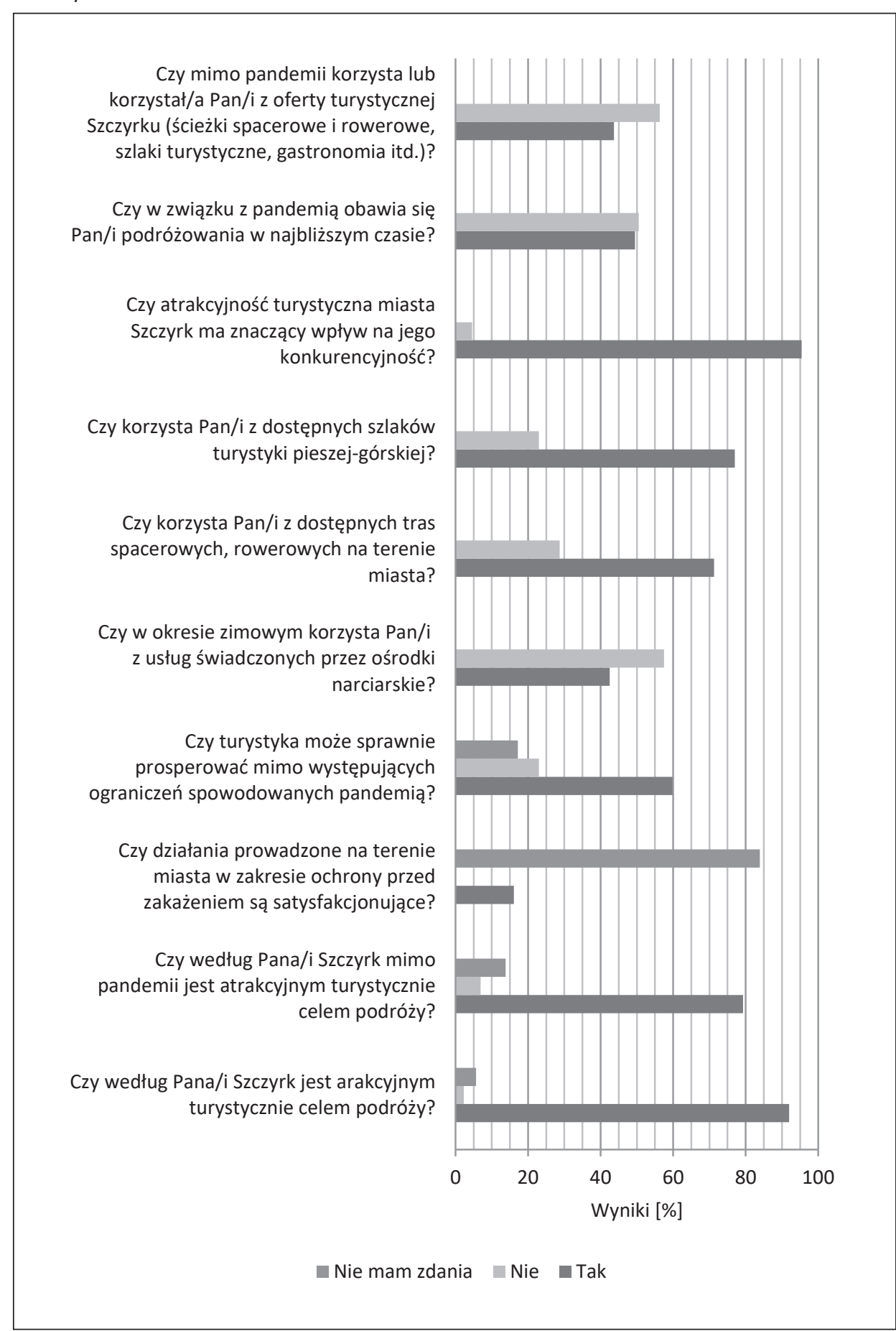

Źródło: Opracowanie własne na podstawie przeprowadzonej ankiety 
Rycina 5. Zadowolenie ankietowanych dotyczące wybranych czynników związanych z turystyką w Szczyrku

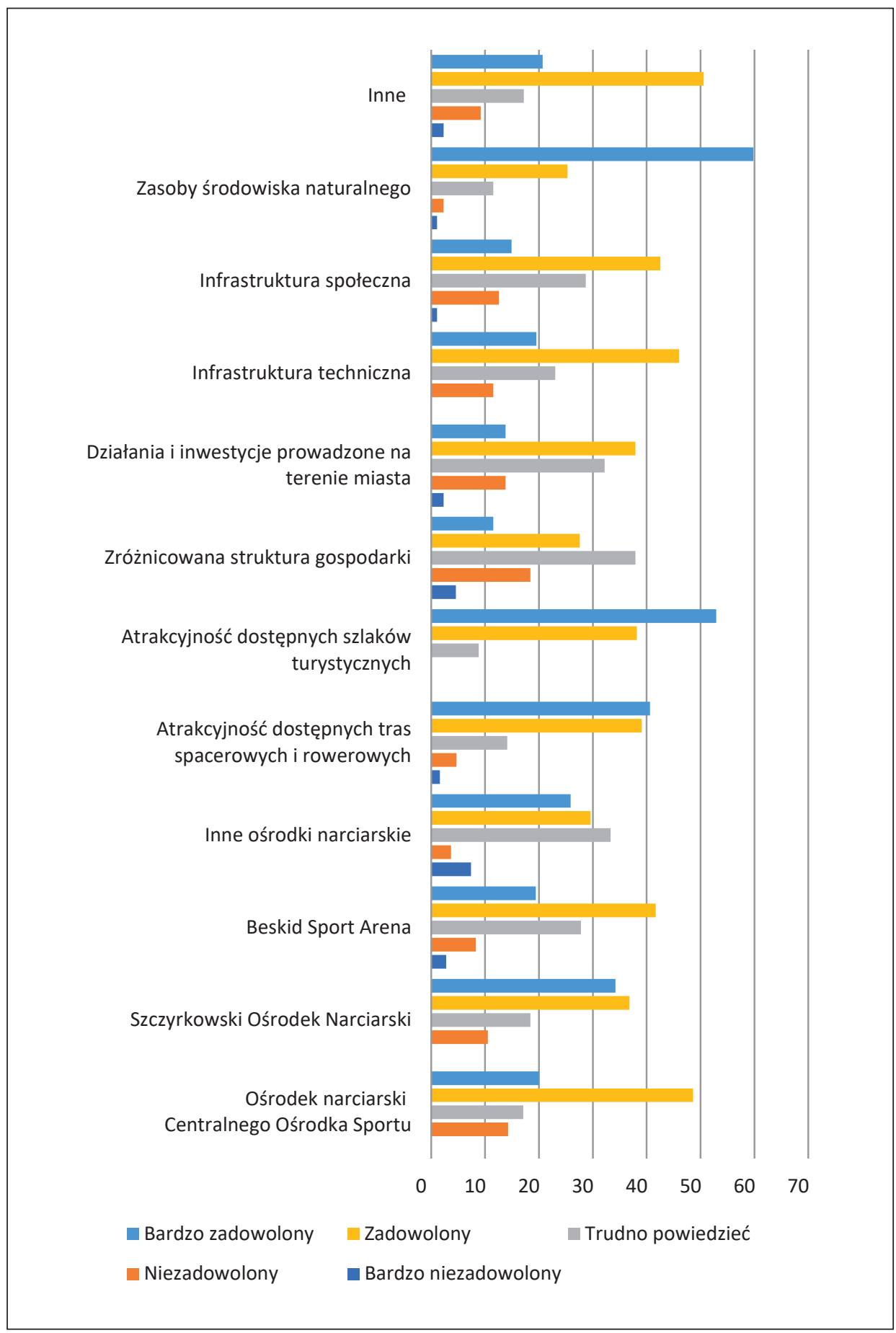

Źródło: Opracowanie własne na podstawie przeprowadzonej ankiety 
BSA oraz pozostałe mniejsze ośrodki. W ocenie ankietowanych dostępne trasy spacerowe i rowerowe, a także szlaki turystyczne są zadowalające lub bardzo zadowalające.

$\mathrm{Na}$ wykresie przedstawiono ponadto zadowolenie respondentów z wybranych czynników kształtujących konkurencyjność regionu. Są to: zasoby środowiska naturalnego, działania i inwestycje prowadzone na terenie miasta, infrastruktura techniczna, infrastruktura społeczna.

Ważnym narzędziem diagnostycznym, które zostało wykorzystane w omawianym badaniu, było przeprowadzenie dwóch wywiadów eksperckich. Na ich podstawie zostały wykonane mapy myśli, za pomocą których przedstawiono kluczowe czynniki decydujące o sukcesie turystycznym miasta oraz czynniki ograniczające jego konkurencyjność.

Kluczowe czynniki wpływające na sukces turystyczny wskazano na podstawie analizy literatury, ankiet i wywiadów eksperckich (rycina 6).

1. Lokalizacja - Szczyrk jest położony w malowniczej dolinie, w paśmie górskim Beskidu Śląskiego. Znajduje się także w dogodnym miejscu lokalizacyjnym ze względu na centralne położenie na południu Polski.

2. Połączenia komunikacyjne - dobry dojazd do miasta mają mieszkańcy Bielska-Białej, Katowic i Warszawy. Ponadto na terenie Szczyku funkcjonują darmowe skibusy.

3. Bezpośrednie inwestycje zagraniczne - inwestycje spółki Tatry Mountain Resorts w Szczyrkowski Ośrodek Narciarski.

4. Infrastruktura turystyczna - Szczyrk charakteryzuje się bardzo dobrze rozwiniętą infrastrukturą. W mieście funkcjonują ośrodki narciarskie, nowe trasy enduro, liczne lokale gastronomiczne, liczne bazy noclegowe oraz szlaki górskie.

5. Ośrodki narciarskie - Szczyrk jest konkurencyjny przede wszystkim zimą ze względu na ofertę ośrodków narciarskich, które spełniają standardy europejskie. Dodatkowym atutem jest to, że główne ośrodki narciarskie w mieście mają wspólny skipass.

6. Wydarzenia - w sezonach letnim i zimowym na terenie miasta odbywają się interesujące wydarzenia. Zaliczyć do nich można Tydzień Kultury Beskidzkiej, Snow Fest, imprezy plenerowe, a także piesze wycieczki prowadzone przez lokalnych przewodników.

7. Promocja - w telewizji są emitowane reklamy zachęcające do przyjazdu. Ważnym narzędziem marketingowym są także social media. Wiele firm promuje swoje usługi na Facebooku i Instagramie. Ponadto coraz częściej ośrodki są reklamowane przez sportowców, aktorów i influencerów.

8. Ciągły rozwój - władze miasta starają się, by spełnić różne wymagania turystów. Świadczy o tym planowana budowa stacji przesiadkowej, parków zabaw i aquaparku.

Natomiast na rysunku 3 przedstawiono elementy, które ograniczają konkurencyjność Szczyrku. Warto zaznaczyć, że Szczyrk jest konkurencyjny mimo swoich słabych stron, jednak należy wprowadzać odpowiednie usprawnienia, dzięki którym pozycja miasta będzie się wzmacniać. Wciąż można wskazać kilka obszarów wymagających usprawnień.

1. Infrastruktura drogowa $\rightarrow$ to główny problem występujący na terenie miasta. Uwarunkowania przyrodnicze ograniczają możliwości zagospodarowania tej przestrzeni. Przez całe miasto przebiega droga jednojezdniowa, a w sezonie zimowym natężenie ruchu drogowego wymagałoby drogi dwujezdniowej. Oprócz tego na terenie miasta znajduje się ograniczona liczba miejsc parkingowych. W związku z tym dobrym rozwiązaniem wydaje się budowa planowanej stacji przesiadkowej.

2. Wygoda turystów $\rightarrow \mathrm{w}$ okresie zimowym niewielu turystów korzysta $\mathrm{z}$ transportu 
Rycina 6. Mapa myśli przedstawiająca kluczowe czynniki wpływające na sukces turystyczny Szczyrku

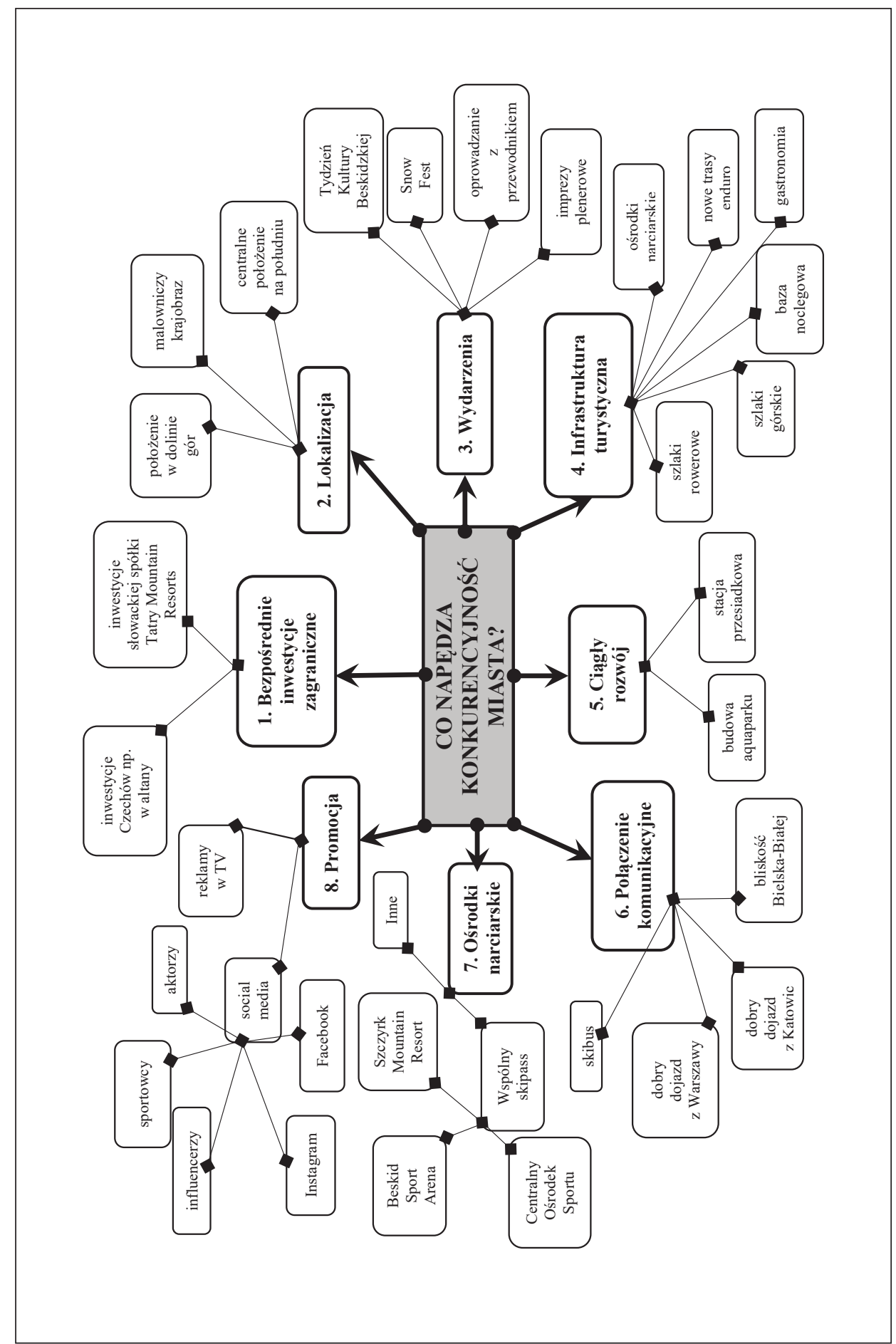

Źródło: Opracowanie własne na podstawie kwestionariusza i wywiadów eksperckich 
Rycina 7. Mapa myśli dotycząca czynników ograniczających konkurencyjność Szczyrku

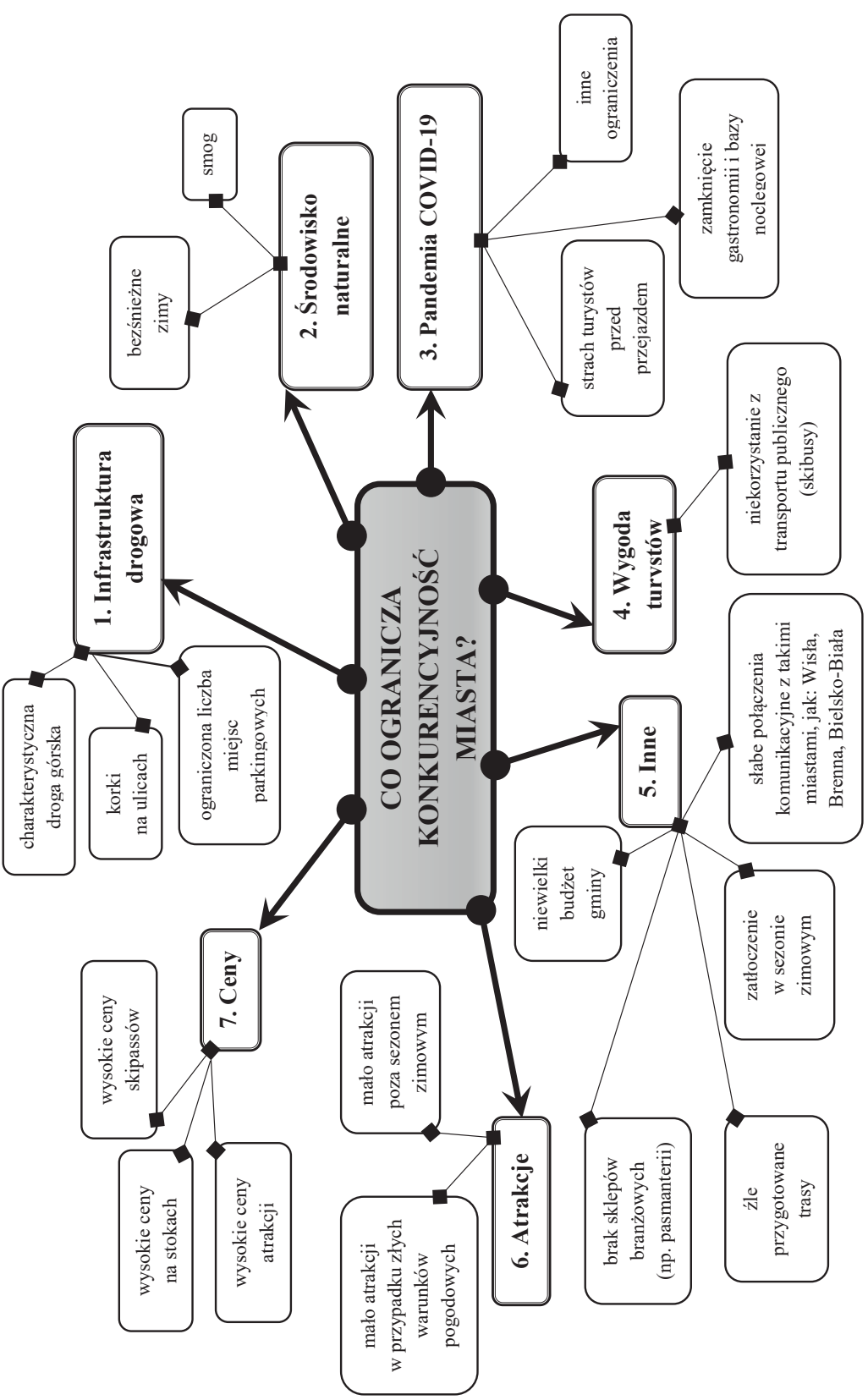

Źródło: Opracowanie własne na podstawie kwestionariusza i wywiadów eksperckich 
publicznego. Wpływa to na jeszcze większe natężenie ruchu drogowego. Budowa stacji przesiadkowej byłaby dobrym rozwiązaniem, choć należałoby postawić pytanie, czy turyści będą z niej korzystać.

3. Środowisko naturalne $\rightarrow$ dolinne położenie miasta przekłada się na zalegające nad nim zanieczyszczenia powietrza. Władze miasta stosują szereg działań mających na celu ograniczenie smogu. Problem stanowią również postępujące zmiany klimatyczne przekładające się na bezśnieżne zimy.

4. Pandemia COVID-19 $\rightarrow$ początkowe zamknięcie gastronomii i bazy noclegowej wygenerowało ogromne straty wśród przedsiębiorców. Turyści obawiali się przyjazdu na Śląsk ze względu na dużą liczbą zakażeń na tym terenie.

5. Atrakcje $\rightarrow$ według badanych miasto nie oferuje wielu atrakcji w sezonie letnim i w sytuacji złych warunków pogodowych.

6. Ceny $\rightarrow$ wysokie ceny skipassów, duże opłaty pobierane na stokach.

7. Inne $\rightarrow$ według badanych ograniczeniami w Szczyrku są także: mała liczba mieszkańców generująca niskie dochody budżetu gminy, brak sklepów branżowych, źle przygotowane trasy narciarskie, zatłoczenie w sezonie zimowym i słabe połączenia komunikacyjne z innymi miastami, np. Wisłą, Brenną.

\section{Podsumowanie i wnioski}

Zasoby środowiska naturalnego stanowią czynnik kształtujący konkurencyjność regionów, dlatego źródłem przewagi konkurencyjnej Szczyrku nad innymi miastami jest jego górskie położenie. Z przeprowadzonych przez autorki badań jednoznacznie wynika, że uwarunkowania przyrodnicze, bezpośrednie inwestycje zagraniczne i inwestycje władz miasta przekładają się na atrakcyjność turystyczną Szczyrku. Należy także podkreślić, że pandemia COVID-19 w znacznym stopniu wpłynęła na sytuację turystyczną w tym mieście.

Literatura

References

Bąk, I., Matlegiewicz, M. (2010). Przestrzenne zróżnicowanie atrakcyjności turystycznej województw w Polsce w 2008 roku. Zeszyty Naukowe Uniwersytetu Szczecińskiego. Ekonomiczne problemy usług, $52,57-67$.

Bielak, M. (2014, 18 sierpnia). Coraz Lepszy Portal Biznesowy. Pozyskano z: https://www.corazlepszyportalbiznesowy.pl/art/przewaga-konkurencyjna

Danielak, W., Stankiewicz, D. (2016). Konkurencyjność przedsiębiorstwa z perspektywy przeglądu podejść i koncepcji rozwoju strategii. Zeszyty Naukowe Uczelni Jana Wyżykowskiego Studia z Nauk Społecznych, 305, 303-316.

Daszkiewicz, N. (2008). Konkurencyjność. Poziom makro, mezo i mikro. Warszawa: Wydawnictwo Naukowe PWN.

Dąbrowska, B.J. (2010). The competition of tourist regions of the world at the $1^{\text {st }}$ decade of the $21^{\text {st }}$ century and its determinants. In: J. Sala (ed.), Competitiveness of cities and regions in global tourism market. Warszawa: Polskie Wydwnictwo Ekonomiczne, 51-66.

Dogan, M. (2012). A Case for Alternative Tourism: Mountain Tourism. In: M. Kozak, N. Kozak (eds.), Conference: 2. Interdiscipilinary Tourism Research Conference. Ankara: Detay Anatolia Akademik Yayıncılık Danışmanlık Org. Turz. Ltd. Şti, 267-277. 
Duglio, S., Beltramo, R. (2019). Mountain tourism in Europe. European Journal of Tourism Research, $22,129$.

Duro, J.A., Perez-Laborda, A., Turrion-Prats, J., Fernández-Fernández, M. (2021, 04). Covid-19 and tourism vulnerability. Tourism Management Perspectives, 38.

Durydiwka, M. (2013). Tourist function in rural areas of Poland. Spacial diversity and changing trends. Miscellanea Geographica - Regional Studies On Development, 17. https://doi.org./10.2478/v10288012-0041-2

Foryś, B. (2000). U stóp Skrzycznego... Czyli historia Szczyrku od czasów najdawniejszych. Buczkowice: Bogusława Foryś.

Ghazali, M., Thompson-Carr, A., Higham, J. (2015). Mountaineering Tourism: Looking to the Horizon. In: M. Ghazali, J. Higham, A. Thompson-Carr (eds.), Mountaineering Tourism. London: Routledge.

Godlewska-Majkowska, H., Skrzypek, E., Płonka, M. (2016). Przewaga konkurencyjna w przedsiębiorstwie. Sektor - Wiedza - Przestrzeń. Warszawa: Texter.

Gössling, S., Scott, D., Hall, M. (2020). Pandemics, tourism and global change: a rapid assessment of COVID-19.Journal of Sustainable Tourism,29(1).https://doi.org./ 10.1080/09669582.2020.1758708

GUGiK. (2021, 15 listopada). Dane udostępniane bezpłatnie do pobrania $z$ serwisu www.geoportal.gov. pl. Pozyskano z: http://www.gugik.gov.pl/pzgik/dane-bez-oplat/dane-z-panstwowego-rejestru-granic-i-powierzchni-jednostek-podzialow-terytorialnych-kraju-prg

GUS. (2021, 15 listopada). Bank Danych Lokalnych. Pozyskano z: https://bdl.stat.gov.pl/BDL/dane/podgrup/tablica

GUS. (2021, 17 listopada). Bank Danych Lokalnych. Liczba udzielonych noclegów. Pozyskano z: https:// bdl.stat.gov.pl/BDL/metadane/cechy/szukaj?slowo=Liczba\%20udzielonych\%20nocleg\%c3\%b3w\#

GUS. (2021, 16 listopada). Bank Danych Lokalnych. Turystyczne obiekty noclegowe i ich wykorzystanie. Pozyskano z: https://bdl.stat.gov.pl/BDL/metadane/cechy/szukaj?slowo=Turystyczne\%20obiekty\%20noclegowe\#

Góralski, P., Lazarek, M. (2009). Czynniki kształtujące konkurencyjność regionów. Zeszyty Naukowe SGGW w Warszawie. Polityki Europejskie, Finanse i Marketing, 1(50), 307-315.

Hall, C.M., Scott, D., Gössling, S. (2020). Pandemics, transformations and tourism: Be careful what you wish for. Tourism Geographies, 22, 1-22. https://doi.org/10.1080/14616688.2020. 1759131.

Higgins-Desbiolles, F. (2020). The "war over tourism": Challenges to sustainable tourism in the tourism academy after COVID-19. Journal of Sustainable Tourism, 29, 551-569. https://doi.org/10.1080/ 09669582.2020 .1803334

Ioannides, D., Gyimóthy, S. (2020). The COVID-19 crisis as an opportunity for escaping the unsustainable global tourism path. Tourism Geographies. An International Journal of Tourism Space, Place and Environment, 22, 624-632.

Juchniewicz, M. (2014). Instrumenty konkurowania podmiotów gospodarczych użytkujących grunty z zasobu własności rolnej Skarbu Państwa. Roczniki Naukowe Stowarzyszenia ekonomistów rolnictwa i agrobiznesu, XVI, 3, 110-114.

Kapera, I. (2018). Sustainable tourism development efforts by local governments in Poland. Sustainable Cities and Society, 40, 581-588.

Knura, J., Borońska, A., Włodrczyk, M. (2016). Prognoza oddziaływania na środowisko miejscowego planu zagospodarowania przestrzennego fragmentu miasta Szczyrk przy ul. Beskidzkiej. Szczyrk: Miasto Szczyrk.

Krukowska, R., Świeca, A. (2011). Tourism Function as an Element of Regional Competitiveness. Polish Journal of Sport and Tourism, 25, 32-43.

Łaźniewska, E., Gorynia, M. (2012). Konkurencyjność regionalna. Warszawa: Wydawnictwo Naukowe PWN.

Mas-Verdu, F., Roig-Tierno, N., Nieto-Aleman, P.A., Garcia-Alvarez-Coque, J.M. (2020). Competitiveness in European Regions and Top-Ranked Universities: Do Local Universities Matter? Journal of Competitiveness, 12, 91-108. https://doi.org/10.7441/joc.2020.04.06 
Marković, S., Perić, M., Mijatov, M., Doljak, D., Zolna, M. (2017). Application of tourist function indicators in tourism development. Journal of the Geographical Institute Jovan Cvijic SASA, 67(2), 163-178. https://doi.org/10.2298/IJGI1702163M

Mazurski, K.R. (2009). Region turystyczny jako pojęcie. Regiony Turystyczne, 21, 7-16

Michalak, J. (2014). Teoretyczne aspekty konkurencyjności regionu. Zeszyty Naukowe Uniwersytetu Szczecińskiego. Problemy Zarządzania, Finansów i Marketingu, 35, 39-48.

Musa, G., Thirumoorthi, T. (2015). Mountaineering Tourism. In: M. Ghazali, J. Higham, A. ThompsonCarr (eds.), Health and safety issues in mountaineering tourism. London: Routledge.

Nawrot, Ł., Zmyślony, P. (2009). Regiony turystyczne na międzynarodowej arenie konkurencji: programowanie rozwoju regionalnego czy zarządzanie przestrzenią zorganizowaną?. Regiony Turystyczne, 21, 31-50.

Nunkoo, R. (2015). Tourism development and trust in local government. Tourism Management, 46, 623-634.

Porter, M.E. (1985). Competitive Advantage: Creating and Sustaining Superior Performance. New York: The Free Press.

Ratajczak-Mrozek, M. (2010). Sieci biznesowe a przewaga konkurencyjna przedsiębiorstw zaawansowanych technologii na rynkach zagranicznych. Poznań: Wydawnictwo Uniwersytetu Ekonomicznego w Poznaniu.

Sheresheva, M., Efremova, M., Valitova, L., Polukhina, A., Laptev, G. (2021). Russian Tourism Enterprises' Marketing Innovations to Meet the COVID-19 Challenges. Sustainability. An Open Access Journal from MDPI, 13(7).

Smętkowski, M. (2011). Polityka spójności a konkurencyjność dużych polskich miast. Studia Regionalne $i$ Lokalne.

Stock, J.H. (2020). Reopening the Coronavirus-Closed Economy. Technical Report. Hutchins Center Working Paper, 60.

Streimikiene, D., Svagzdiene, B., Jasinskas, E., Simanavicius, A. (2021). Sustainable tourism development and competitiveness: The systematic literature review. Sustainable Development, 29, 259-271. https://doi.org/10.1002/sd.2133

Szromek, A.R. (2013). Pomiar funkcji turystycznej obszarów za pomocą wskaźników funkcji turystycznej na przykładzie obszarów państw europejskich. Studia Ekonomiczne.

TMR. (2021, 15 listopada). Szczyrk Mountain Resort. Pozyskano z: https:/www.tmr.sk/o-nas-/orodki/ szczyrk-mountain-resort

Tregua, M., D’Auria, A., Marano-Marcolini, C. (2018). Oleotourism: Local Actors for Local Tourism Development. Sustainability, 10(5).

Yu, M., Li, Z., Yu, Z., He, J., Zhou, J. (2020). Communication related health crisis on social media: A case of COVID-19 outbreak. Current Issues in Tourism, 1-7. https://doi.org/10.1080/13683500.2020.1 752632

Ziętara, W. (2014). Pozycja konkurencyjna polskich gospodarstw rolnych na tle gospodarstw wybranych krajów europejskich. Problemy Drobnych Gospodarstw Rolnych, 4, 63-78.

Martyna Cader, absolwentka kierunku gospodarka przestrzenna na Uniwersytecie Rolniczym w Krakowie. Do jej zainteresowań naukowych należą zagadnienia związane z konkurencyjnością, rozwojem lokalnym i badaniami społecznymi. Pracuje na stanowisku asystenta do spraw opracowywania danych w branży zajmującej się m.in. ewidencją oraz przeglądami technicznymi dróg i obiektów mostowych na terenie jednostek samorządu terytorialnego w kraju.

Martyna Cader, a graduate of Spatial Planning at the University of Agriculture in Krakow. Her research interests include issues related to competitiveness, local development and social research. She works in the industry dealing with, among others, records and inspections of roads and bridges in local government units in the country, as an assistant for data processing 


\section{Adres/Address:}

e-mail: martyna.cader96@gmail.com

Julia Gorzelany, dr nauk ekonomicznych, specjalność: nauki o zarządzaniu. Jest certyfikowanym Trenerem Talentów i Mocnych Stron Gallupa. Posiada międzynarodową akredytację ACC ICF, a także jest trenerem biznesu z międzynarodowym certyfikatem IES London. Jej badania zaowocowały ponad 50 pracami naukowymi. Zainteresowania naukowe: zarządzanie organizacją, ekonomiczne i społeczne czynniki zagospodarowania przestrzennego, rozwój i konkurencyjność regionalna, umiejętności miękkie.

Julia Gorzelany, $\mathrm{PhD}$ in economics, with a specialty in management sciences. She is a certified Strengths Community Coach and holds an international ACC ICF accreditation, is also a business coach with an international IES London certificate. Her research resulted in over 50 academic papers. Research interests: organisation management, economic and social factors in land management, regional development and competitiveness, soft skills.

ORCID: https://orcid.org/0000-0002-4340-0042

\section{Adres/Address:}

Uniwersytet Rolniczy w Krakowie

Katedra Gospodarki Przestrzennej i Architektury Krajobrazu

ul. Balicka 253 c

30-149 Kraków, Poland

e-mail: j.gorzelany@ur.krakow.pl 